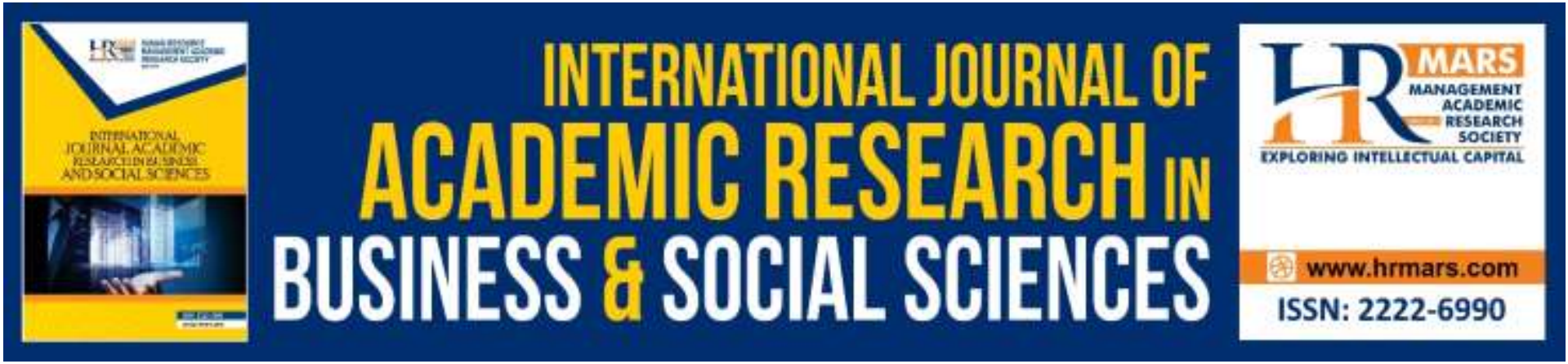

\title{
Indigenous Education Rights: The Malaysian Case
}

\section{Mohd Roslan Rosnon, Mansor Abu Talib}

To Link this Article: http://dx.doi.org/10.6007/IJARBSS/v9-i10/6470

DOI: $10.6007 /$ IJARBSS/v9-i10/6470

Received: 10 September 2019, Revised: 30 September 2019, Accepted: 10 October 2019

Published Online: 31 Oct 2019

In-Text Citation: (Rosnon \& Talib, 2019)

To Cite this Article: Rosnon, M. R., \& Talib, M. A. (2019). Indigenous Education Rights: The Malaysian Case. International Journal of Academic Research in Business and Social Sciences, 9(10), 149-167.

Copyright: ( 2019 The Author(s)

Published by Human Resource Management Academic Research Society (www.hrmars.com)

This article is published under the Creative Commons Attribution (CC BY 4.0) license. Anyone may reproduce, distribute, translate and create derivative works of this article (for both commercial and non-commercial purposes), subject to full attribution to the original publication and authors. The full terms of this license may be seen

at: http://creativecommons.org/licences/by/4.0/legalcode

Vol. 9, No. 10, 2019, Pg. 149 - 167

Full Terms \& Conditions of access and use can be found at http://hrmars.com/index.php/pages/detail/publication-ethics 


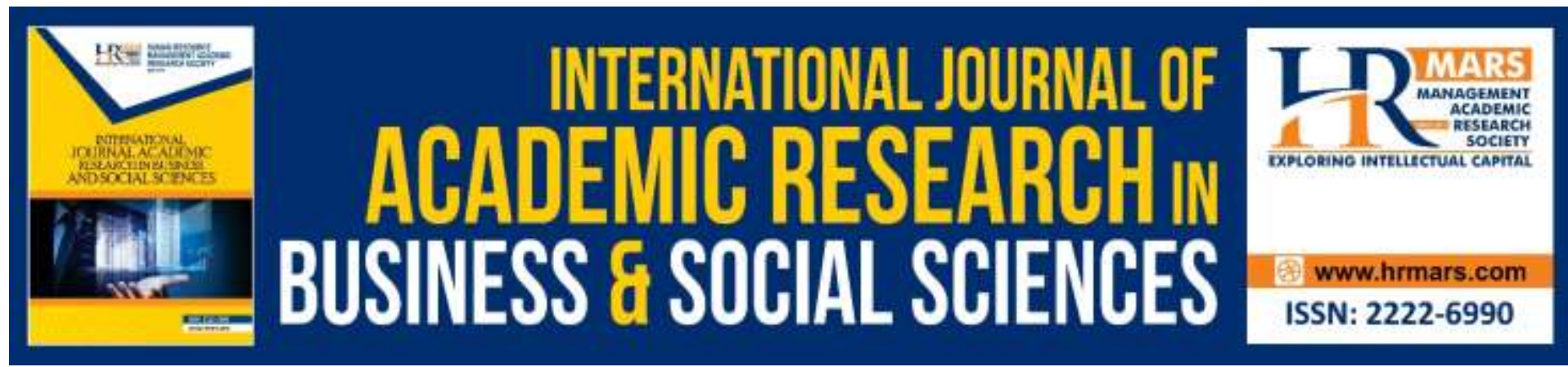

\title{
Indigenous Education Rights: The Malaysian Case
}

\author{
Mohd Roslan Rosnon ${ }^{1}$, Mansor Abu Talib² \\ ${ }^{1}$ Department of Social \& Development Sciences, Faculty of Human Ecology, Universiti Putra \\ Malaysia, 43400 Serdang, Selangor, Malaysia, ${ }^{2}$ Department of Human Development and \\ Family Studies, Faculty of Human Ecology, Universiti Putra, Malaysia, 43400 Serdang, \\ Selangor, Malaysia.
}

\begin{abstract}
United Nations Declaration on the Rights of Indigenous Peoples (UNDRIP) was created to give Indigenous peoples the right to determine their own educational system. In article 14 it is stated that, Indigenous peoples have the right to establish and control their educational systems and institutions, providing education in their own languages; in a manner appropriate to their cultural methods of teaching and learning. Ever since the 61 years of independence, Orang Asli has never been neglected or excluded from the government's planning in ensuring their education development. Therefore, this paper relied on the qualitative approach using secondary data. This paper reviews the current and the past reports from 1995 until 2015 that reflect the shifts in government policy of Indigenous education in Malaysia. The data were then analysed using thematic analysis. Evidences from a range of reports, have been utilised to shed light on why Indigenous peoples' educational disadvantage persists, despite extensive government and community effort and resources. This paper also highlights and recommends the self-determination, equity and recognition for Orang Asli education system. Furthermore, Orang Asli have the best knowledge of their culture and curriculum needs and the most appropriate approach, which enable them to cater for their own particular circumstances and create a successful outcome in the development of Indigenous education policy.
\end{abstract}

Keyword: Indigenous Education Policy, Orang Asli, Equity, Recognition, Human Rights

\section{Introduction}

The United Nations International Decade (1995-2004) addressed some issues such as human rights, the environment, development, health, culture and education during the second session of the UN Permanent Forum on Indigenous Issues. One of the aims of the Forum was the discrimination suffered by Indigenous peoples in the education system, the loss of Indigenous languages, the exclusion of Indigenous cultures and knowledge from the school curricula, and the need to promote the participation and contribution of Indigenous peoples in the development of culturally and linguistically appropriate educational programs. For this reason the United Nations Declaration on the Rights of Indigenous Peoples (UNDRIP) is created to give Indigenous peoples the right to determine their own education system (UNDRIP, 2007). Article 14 states that, Indigenous peoples have the right to establish and 
control their educational systems and institutions and provide education in their own languages; in a manner appropriate to their cultural methods of teaching and learning. Moreover, Indigenous individuals, particularly children have the rights to all levels and forms of education of the state without any discrimination (UNDRIP, 2007).

Education for indigenous peoples cannot be considered in isolation from the issues of discrimination, democracy and human rights. Article 6 of the World Declaration on Education for All states that, successful learning can only take place in healthy and culturally appropriate environments as learning connects many aspects of life with the well-being of the learner (UNESCO, 2000, p. 8). Furthermore, Indigenous education is within the context of contemporary discussions on how it is linked with cultural, linguistic and biological diversity as well as its association with issues of identity, survival and sustainability (Mohd Roslan, 2014, 2016). Education is a prerequisite, and a tool for enhancing the opportunities for learners to exercise their social, cultural, economic, civil and political rights and responsibilities. Education for Orang Asli must therefore be considered on the basis of recognition and understanding and promotion of human rights specifically the rights to cultural identity in which it can also contribute to the pluralist societies (Mohd Roslan, 2014; Mohd Roslan \& Sara, 2015).

In Malaysia, the development of Orang Asli via education is significantly in line with the physical growth of infrastructural and modern agricultural methods introduced by the government in 1960 (Asnarulkhadi, Maria, Zahid, Mariani, \& Hanina, 2007). The measures taken to improve the quality of the life of the Orang Asli and their education in particular, are not new. The government of Malaysia has introduced initiatives to integrate minority groups into the mainstream and this can be seen as a measure to fulfil social participation (Asnarulkhadi, 2005; Roslan, 2010; Sarjit, Roslan, \& Ma'rof, 2010). In Malaysia, these initiatives constituted part of the Second Malaya Plan (1961-1965) until the Tenth Malaysia Plan (2011-2015). However, the curriculum is developed and modelled on mainstream curricula without taking any account of the Orang Asli cultural issues (Mohd Roslan, 2014; Mohd Roslan \& Sara, 2015). However these cultural issues are not incorporated in the educational process in which it can actually help to preserve the culture or even apply the knowledge in the classroom setting.

The integration of minority groups into the mainstream curricula is based on policies created by the government with the intention to provide the best education for the Indigenous people. However, the efforts and policies established by the government to increase education among the Orang Asli has resulted in vain as studies showed that these efforts do not provide the best education for them (Hasan, 2009; Hasmah, 2013; Nicholas, 2006). In terms of education, aboriginal communities are still far behind compared to the mainstream society (Hasan, 1997, 2009; Hasmah, 2013; Nicholas, 2006; O. Omar, 2004; Sumathi, 2016). For almost 60 years of mainstream education for the Orang Asli, the education issues for Indigenous groups have not been resolved. This lack of progress in education begs the question: is the education policy made by the government today more beneficial to the mainstream society than to the Orang Asli community? This question remains important because the Orang Asli are still behind in terms of educational achievement (see the report of Department of Orang Asli Development, 2011). The mainstream education system is 
rejected by the Orang Asli in Malaysia (Mohd Roslan, 2013; Nicholas, 2006; Tijah \& Joseph, 2003). This situation is often characterized by a lack of access to an education that respects the diverse cultures and languages of the Orang Asli. Despite of this evidence, the government in Malaysia seems to ignore the issues raised by the Orang Asli and continues to impose a mainstream education system on them (see the report of SUHAKAM, 2011a; SUHAKAM, 2011b, 2012).

This paper argues that Orang Asli has education system which has a mainstream orientation and very little consideration is given to the educational requirements, cultural context and also languages of Indigenous peoples. This has indirectly impacted the educational outcomes for Indigenous students with limited acknowledgment of the rights of Indigenous people in the education system. Therefore, it is important for educators to address educational disadvantage and the rights of Indigenous people in schools because it can contribute to social justice and hinder the learning process and education outcomes. This paper provides analysis of the current practices and policy of Indigenous education that can contribute to improving the current policy and ensuring justice for all students. These issues remain important in improving equity and self-determination among Indigenous people and ensuring social justice for Indigenous peoples in Malaysia.

Therefore, my argument is that the rights to education for the Orang Asli should be based on minimum standards promoted by the United Nations Declaration on The Right of Indigenous peoples (UNDRIP), which states that 'Everyone has the right to education' (Article 26.1) and that 'Parents have a prior right to choose the kind of education that shall be given to their children' (Article 26.3). Access to education is important in determining positive socio-cultural outcomes of people in all societies. It is critical that cultural models of education are respected and recognized and not simply 'tolerated' in order for different frameworks to co-exist and for all students to have equal access to education within culturally diverse societies (Mohd Roslan, Mansor, \& Nik Alia Fahada, 2019). For example, the concept of tolerance which was introduced by Derrida (2006) in his work The Politics of Friendship stresses that tolerance is something unconditional and will benefit both sides. Tolerance is in this way subsumed in a responsibility for the other. Tolerance is surpassed in accordance with one's own will and desire, one takes as one's task the fulfilment of the desire of the life-project the other cannot actualize.

\section{International Standards for Orang Asli Education Rights: The UNDRIP}

In pledging to pursue in the spirit of partnership and mutual respect, international communities, including Malaysia should reflect on the contemporary standard made by UNDRIP (Mohd Roslan, 2016). This is supported in preambular para. 24 which clearly mentions about this pledge made by the UNDRIP and UN General Assembly (Subramaniam, 2011). Hypothetically, the UNDRIP lays out a 'roadmap for future realisation of Indigenous rights' (Gilbert \& Doyle, 2011, p. 327). Malaysia, which is the member of the UN and the UN Human Rights Council protects human rights under arts 1(3), 13(1)(b), 55(c), 56, 62(2) and 76(c) of the Charter of the United Nations (UN Charter). As for these provisions, art 56 of the UN Charter member states that 'to take joint and separate cooperation with the organization' for the protection and promotion of human rights and the fundamental freedoms under art 55. As a member of the Human Rights Council, Malaysia is further compelled to 'uphold the 
highest standards in the promotion and protection of human rights' (United Nation, 2006 para 9).

In Malaysia, the UNDRIP is in favour. The Malaysian national human rights institution; SUHAKAM has cited the UNDRIP as a standard reference in their respective calls for the protection of the Orang Asli education rights. There are three international instruments that specifically address guaranteed Indigenous rights and educational rights to indigenous peoples and indigenous children besides UNDRIP. They are International Labour Organization (ILO) Convention 169 Concerning Indigenous and Tribal Peoples in Independent Countries (ILO 169) (Article 27 (1), (2), (3), 28 (1), (2), (3), 29(1), (2) \& 31), which make reference to the UN Convention on the Rights of the Child (CRC) (Article 2, 28, 29 \& 30) and the UN Universal Declaration of Human Rights (UDHR) (Article 26(1) \& 29(2)). All international allocations indicate that education is important and should be prepared by taking into account things like culture, the practice of their own language without being discriminated and the community's way of life. The access to education is human right and education has the power to change which is why Malaysia should take the international standard as a guideline in implementing and making the education policy to the Orang Asli.

\section{Education Development of Orang Asli in Malaysia}

The Malaysian government operates significantly in line with the physical growth and modern agricultural developments occurring in the country. These changes have impacts on the advances made in developing a suitable education policy for this group. Initiatives taken by the Malaysian government to integrate Orang Asli into the mainstream can be seen as a measure of social inclusion (Asnarulkhadi, 2005; Mohd Roslan, Sarjit, Shamsul Azahari, N Alia Fahada, \& Adam Danial, 2019). These initiatives formed as part of the Second Malaya Plan (1961-1965) until the Tenth Malaysia Plan (2011-2015). Malaysian Government believes that education is the main agenda in the Orang Asli's development programs and key mechanism in improving the quality of life among the Orang Asli. Before the year 1995, schools and all education programs for Orang Asli were managed by the Department of Orang Asli Affairs (JHEOA). JHEOA managed the Orang Asli's school and education programs on their own and JHEOA aimed to give preparation needed by the Orang Asli children upon entering the mainstream education.

However, the education system managed by JHEOA was a failure (see Ikram, 1997). The factors which contributed to this failure were the untrained teachers, insufficient funding and lack of knowledge among the educators in terms of the Orang Asli cultures and traditions (Department of Orang Asli Affairs, 1995). Thus, in the conclusion of the Sixth Malaysia Plan (1991-1995), in order to improve the delivery system of education to the Orang Asli, effective on January $1^{\text {st }} 1995$, all administration and management of the Orang Asli education has been taken over by the Department of Orang Asli Development (JAKOA) from the Ministry of Education. Previously the Department of Orang Asli Development (JAKOA) was known as the Department of Orang Asli Affair (JHEOA). However, the responsibilities of School and Hostel 1996, JAKOA, via its Chief Director is still responsible to the Commissioner for the Aboriginal Affairs under Section 4, Act 134, of the Aboriginal Peoples Act 1954 (Revised 1974) (Department of Orang Asli Development, 2011) in the administrative affairs and the welfare and the development of the Orang Asli. All school buildings, hostels, teachers and supporting 
groups as well as students that were managed by JAKOA are then administered by the Ministry of Education. This was the first step taken by the Malaysian government in integrating the education for the Orang Asli into the mainstream education.

The Orang Asli community was in the limelight in the Malaysia Second Plan by the government which stated that the position of the Orang Asli community in the socio-economy was being left behind. Furthermore, the government felt that the education was one of the main factors in contributing to the Orang Asli's socio-economic status. Through the National Development Policy, the report of Memorandum of Understanding of the Acquisition of School under the Department of Orang Asli Affairs to the Ministry of Education undertakes to provide more efficient and effective educational service. This is actually the first step taken by the government to take a serious action and plan regarding the importance of the Orang Asli's education system after the JHEOA's failure in managing the Orang Asli education system. The government believes that the Orang Asli are able to escape from poverty by having education. Memorandum of Understanding the Acquisition of School under the Department of Orang Asli Affairs is discussed in the following section.

A few initiatives to empower the advancement of the Orang Asli's education were implemented in the Eighth Malaysia Plan (RMK8) (2000-2005) and the Ninth Malaysia Plan (RMK9) (2006-2010). In addition to the government pursuant to the Tenth Malaysia Plan, a certain amount of budget was allocated to increase the access to education. Thus, the Special Model School (Special Model School) would help to overcome the rising dropout rate in secondary school because the students live in remote areas far from their school (Economic Planning Unit, 2010). With the various incentives introduced by the government, the number of Orang Asli students present in schools has increased from year to year in both primary and secondary school levels (Asnarulkhadi et al., 2007). The percentage of dropout in Orang Asli students in secondary schools is at a relatively high level especially from the transition phase from primary school to secondary school. The percentage of dropouts in the year of 2006 (34.50\%), 2007 (34.50\%), 2009 (31.10\%), 2009 (31.77\%) and had declined even more in the year 2010 (29.02\%) (Department of Orang Asli Development, 2011, pp. 45-49). The dropout rate amongst the Orang Asli children, still remain a great cause for concern. One of the main reasons for the problem is the students' poor academic achievement. This issue shows that there are weaknesses in the country's education system as far as the Orang Asli issues are concerned.

Through various Malaysia Plans, education for the Orang Asli community remains in focus and gets attention by the government. Even though various programs for the education policy under the annual budget have been carried out to the Orang Asli, these programs do not seem to benefit them at all. Thus, the government has to instil seriousness in helping the Orang Asli community to ensure the government's goals to eradicate poverty through education can be achieved. Therefore, the government's receptiveness and the community member's involvement in the decision making on a certain policy are important to ensure the ongoing effort is effectively executed.

Since the independence in 1957, the Malaysian government has introduced various comprehensive development programs to improve and develop the quality life of the Orang 
Asli. The Ministry of Education is committed to improve the delivery system of education to the Orang Asli and effective on January 1st 1995, all administration and management of the Orang Asli education is taken over by the Ministry of Education from the Department of Orang Asli Developments. However, whilst the number of Orang Asli children enrolled in primary and secondary schools has increased significantly over the last decade, the dropout rate amongst the Orang Asli children still remain a great cause for concern. One of the main reasons for the problem is the students' poor academic achievement (Hasmah, 2013; Sharifah et al., 2011). Other contributing factors to the problems among them are culture, school location, poverty, pedagogy and many more (Johdi \& Razak, 2009; Asri, 2012).

\section{Methodology}

This research is based on document analysis is a form of qualitative research in which documents are interpreted by the researcher to give voice and meaning around an assessment topic (Bowen, 2009). Analysing documents incorporates coding content into themes similar to how focus group or interview transcripts are analysed (Bowen, 2009). Secondary sources consisting of 11 documents from Malaysian government reports, papers and policy reports that relate to Indigenous education were reviewed in this research. The reviews and discourse of government reports, papers and policy documents is essential to evaluate and analyse the formulation and development of Indigenous education policy in Malaysia during the important key period when government policy relating to the Indigenous people shifted between 1995 and 2015. Thematic analysis has been chosen to discuss the findings based on the themes that were then identified as outcomes from this document analysis.

\section{Result and Discussion}

\section{Orang Asli Education Policies Discourse Between 1995-2015}

According to reports from 1995 to the late 2015, various issues were mentioned with regards to the Orang Asli education. It started after the adoption of schools from JHEOA in 1995 (Department of Orang Asli Affairs, 1995) in which JHEOA failed in managing the Orang Asli schools where they wanted to integrate the Orang Asli into the mainstream community through the education system. Though it aimed to provide the right and equity to the Orang Asli, its implementation was not towards the goals set. Two clear approaches were used by the government in this era which were assimilation and disadvantage. This integration process was a process to assimilate the Orang Asli community into mainstream society so that they can get out of poverty through the education system (Ikram, 1997; Mohd Asri, 2012; Nicholas, 2006). Besides of the weak results of JHEOA in managing the Orang Asli education, the government took the opportunity to integrate the Orang Asli into mainstream education system in order to solve the issue of poverty (see the memorandum report inDepartment of Orang Asli Affairs, 1995).

At the end of 1990s and the early 2000s, the main focus of the government was to bridge the education gap among Orang Asli with the mainstream people (see the reports of Department of Orang Asli Affairs, 2001a, 2001b, 2002a; Department of Orang Asli Affairs, 2002b). Various efforts were taken via the Action Plan for the Orang Asli Education Development, among them was, the government outlined a comprehensive range of measures to ensure the education gap between the Orang Asli and the mainstream people could be bridged. However 
approaches used by the government were still the same, in which to integrate the Orang Asli community and introducing a parental involvement into the education system. Participation was an activity where the parents will be given an adult education in the activity participated at the school. This was to ensure that the parents were well exposed with the school's activities and to attract students' interest in coming to school. The participation aimed to give awareness to the parents that education is important for their children. Yet, by integrating the mainstream education system, the Orang Asli rejected the education system because the mainstream education system made the Orang Asli students assimilated themselves with the mainstream society (Nicholas, 2006; Sharifah et al., 2011). It is the fact that the Orang Asli community holds strongly to their culture, customs and procedure and they need an education system where it is oriented towards their community.

Participation must be comprehensive in various stages especially in the decision making in which the inspiring views of the Orang Asli community can be instilled directly into the national education system. The approach used to fill the education gap was not inclusive. It is clear that the educational system provided for the Orang Asli is still not taking into account the cultural differences which lead the Orang Asli children to feel the pressure in the mainstream education system. This issue leads to other issues that exist among the Orang Asli children such as discrimination and isolation in the mainstream education.

Thus, it can be concluded that this era did not give any focus to problems regarding to the educational issues such as discrimination, cultural issues and also the rights in terms of the existing curriculum and the educational programs in order to enhance the educational system of the Orang Asli community. Even though the previous plan which aimed to bridge the education gap between the Orang Asli community and the mainstream it failed to reflect the plan was as seen as a fiasco. This is because in a report by JHEOS (2008) on the Orang Asli education achievement from the year 2000 to 2008, the percentage of the Orang Asli dropouts who did not finish high school in 2008 was $47.8 \%$. Meanwhile the percentage of the Orang Asli dropouts who completed Standard 6 but did not continue their schooling to Form 1 in the year 2008 was $29.5 \%$ as compared to 2000 which was $21.8 \%$ (Department of Orang Asli Affairs, 2008, pp. 38-50). This showed the increasing failures in depicting the plan which was intended to fill the gap in education between the Orang Asli community and the mainstream students.

By recognizing the weaknesses, the government has implemented KAP in improving the existing educational system, so that Orang Asli will not be discriminated against and marginalized by the mainstream education system (Ramlah, 2009; Salbiah, 2007). However, the implementation and management of KAP had failed and did not achieve the expected outcomes. As reported by SUHAKAM, there was a problem in terms of the implementation of KAP in which it was not thorough and also the preparation and trainings for educators were not comprehensive which had caused the implementation of the curriculum to fail (see report in SUHAKAM, 2010, 2011b). KAP was originally developed as taking into account cultural differences and integration of environmental elements in ensuring that the community involvement in the education system had reached the Orang Asli community. This is due to the fact that the Orang Asli is too attached to their environment and culture (Andaya, 2001; Carey, 1976; Hasan, 2009; Hood, 2004; Mohd Roslan, 2010; Nicholas, 2005, 2006). 
Since 2010, the government has been under a lot of pressures to ensure that the Orang Asli education system is at a good level. However SUHAKAM, continues to criticize the policies undertaken by the government to ensure that the Orang Asli education system is flawless. Approaches highlighted by SUHAKAM are rights, equity and recognition (see the report by SUHAKAM, 2010, 2011b; SUHAKAM, 2012). This approach is to provide rights and recognition of the Orang Asli through cultural and language in the curriculum. Trainings should also be given to educators so that they will have adequate knowledge about the Orang Asli. SUHAKAM takes the initiative to grasp disadvantages in the existing education system so that there would be room for improvements in the education system thus making it more inclusive and acceptable by the Orang Asli community. Various recommendations are given by SUHAKAM in ensuring that the Orang Asli children get a better education system (SUHAKAM, 2012).

In July 2012, the National Transformation Orang Asli Education Plan was launched by YAB Tan Sri Dato' Haji Muhyiddin Yassin, Deputy Prime Minister who were also the Minister of Education. The plan outlines seven new initiatives in an effort to aid the Orang Asli community to blend in the prime society with the progress of Malaysia in which, this plan will be inserted in the Malaysia Education Development Plan 2013-2025 (see in the plan from Ministry of Education Malaysia, 2012a). The National Transformation Plan for the Orang Asli Education aims to strengthen the school's authority by incorporating Basic Vocational Education elements to reduce the dropout rate by $6 \%$ starting the year of 2013 (Ministry of Education Malaysia, 2012c). The elements discussed are, increase in the students' intake for the special program for Bachelor of Teaching (PISMP), improve the Orang Asli's education infrastructure, strengthen cooperation (smart partnership) and establish a School Performance Tracking System and Orang Asli students (Ministry of Education Malaysia, 2012a). This plan is a continued issue from the Interim Strategic Plan 2011-2012 which acts as a continuation for the Main Education Development Plan 2006-2010. Briefly, both of the plans aim to strengthen the current actions and initiatives in stimulating changes into the education system and determining the new dimension in reaching the excellence in the quality of education (Ministry of Education Malaysia, 2012a).

Even though variety initiatives or action plans have been initiated towards the Orang Asli education system, they did not give major and strong changes. According to the report in the Malaysia Education Development Plan, 2013-2015 (2012a, p. 4.12) states that '...the Ministry will keep on ensuring the students' special needs such as special education students, aboriginal students and the other minority groups such as Orang Asli and Penan, gifted students, as well as schools with less students. The students should have the same opportunities in getting the education which relevant to their needs'. This is an equity issue which has been discussed clearly by the government for the first time regarding the Orang Asli. However, this equity mechanism is not explained in detailed on the Orang Asli's educational rights. The mechanism used is the same issue that was issued in the previous report with regards to the continuation of the KAP program.

Thus, the government perception towards the equity concept is questionable. This is because, the Orang Asli are not given the rights to their education system through school concept by using their own curriculum unlike other races such as Chinese and Indian. Whereas the 
government should ensure every needs are consistent with the national education philosophy. Furthermore, all of the issues and problems faced by the Orang Asli children should be resolved with haste, without neglecting the sociocultural practice. The issues discussed are not only related to the Orang Asli children but also the consideration of the best mechanism regarding to the pedagogy and the curriculum in the teaching and learning system. It is evident in this report (see Ministry of Education Malaysia, 2012a, p. 4.17) that the government plans to increase the provision of teacher support and training programs by adding more prospective teachers among the Orang Asli into the Institute of Teacher Education (IPG), as well as strengthening indigenous resources for the research studies in all five National Indigenous Pedagogy Excellence Centre. However, this proposal must be accompanied by consistent action from the government in helping the Orang Asli community through education.

The second phase of the plan, (2016-2020), in this report, the government states that (Ministry of Education Malaysia, 2012a, p. 4.17) '...focus is on the effort taken in improving learning outcomes and curriculum standards for all indigenous students and other minority groups by using a specially designed intervention...' and '...the ministry will also review the KAP program to determine either the program should be expanded in terms of its implementation whether in the lower level or upper level, or repealed after the basic literacy and numeracy have been mastered by the students'. If the KAP program is continued, the Ministry will review the needs for the establishment of the UPSR examination papers in accordance with the KAP curriculum standard. This is not a new issue and it has been discussed in the previous reports. The government's intention should be realized with initiatives, and action should be taken to ensure the program is executed well. It has been desired by the Orang Asli since the KAP program is introduced, but there is no change and clear action taken by the government in realizing this program successfully. Moreover, the KAP programs could not be continued in certain areas in Malaysia due to problems in executing their programs which were believed to be confusing to some teachers (see SUHAKAM, 2010, 2011b). Therefore, the government should take the matter more seriously in helping the Orang Asli community and give them the rights and equity in determining their education system with their own views and inspiration.

Even though, government is committed to provide equal education and rights in the programs or the development of the education policy for the Orang Asli community, they still feel marginalized by the existing education system (Hasan, 2009; Mohd Roslan, 2013; Nicholas, 2006). This is because the existing education system fails to represent them in recognizing their culture, their background and their language. Weakness that could be identified in the highlighted report is that each agency or entity failed to showcase the real issues in the education system of the Orang Asli community. The main focus is more on the education infrastructure. Whereas elements of rights and recognition in culture, indigenous knowledge, language and history are not highlighted for the government to see that the education system is supposed to help the Orang Asli in achieving their goals and objectives. Therefore, the involvement from the Orang Asli community should not just on the participation in the implementation of a policy but rather across various levels, especially from the construction of a policy and program. This is to ensure that input and views based on their inspiration and 
stand point are integrated in the education policy. A summary of education development for the Orang Asli in the different phases is illustrated briefly in Figure 1.

Figure 1: Phase of Education Development Policy for Orang Asli

$\begin{aligned} & \text { 1995s } 2000 s \\ & \text { Assimilation }\end{aligned} \begin{aligned} & \text { And Integration to mainstream society } \\ & \text { 'Bridge the education gap' } \\ & \text { Participation community }\end{aligned}$
Bi-cultural Education
Oack of involvement and self-determination in Education policy making
Orang Asli Education: Equity and Recognition

The involvement in the policy making in the Indigenous Education Policy involves groups of politicians and bureaucrats who are appointed by the government (see in the Report of Department of Orang Asli Development, 2011; Ministry of Education Malaysia, 2012a). These groups act as mediators in voicing out opinion and knowledge from the community. The formation of a policy involves people from the government sector which then be forwarded to the Ministry. For example, in the Malaysia context, JAKOA is a body which acts as an authority appointed by the government to represent the Orang Asli in determining the policy for them. JAKOA is the body established by the government to look after the well-being of the Orang Asli. It has inherited the paternalistic policy over the affairs of the Orang Asli from the British colonial administrator and has, to a certain extent, weakened the ability of the peoples to exercise their rights to self-determination and autonomy (Rohaida \& Witbrodt, 2012).

Even though the Federal Constitution of Malaysia allocates an appointment of a Senator by the Yang di-Pertuan Agong (King) to represent Orang Asli, the appointment of only one Orang Asli Senator is considered insufficient by the Orang Asli themselves. The role and power of a Senator is only active in the Senate therefore the power entrusted to the Senator has its limits because they are not from the group of politicians who can influence a particular policy (see in Hussain, 1990; Ibrahim, 2008; E. Omar, 1980). Even though a senator is able to advice on the education matter but everything is subjected to the end result by the Minister in the Ministry of Education. This shows that the Orang Asli is not autonomous which agrees with statement made by Rohaida and Witbrodt (2012) and Subramaniam (2011).

Besides, the Orang Asli do not have any political party which can represent them and decide on the decision in the policy making (see in Rohaida \& Witbrodt, 2012). It shows that the Orang Asli are not dominants in the governance system in the policy making as discussed. The Orang Asli do not have a political party which represents them especially in the policy making decision which resulted to them having less autonomy concerning their own matters and no self-government of their own. This Political party is important to ensure that their voices are being brought to the stage where decision-making in the policy takes place. The policy making is determined by the cabinet which consists of the MPs (see in Hussain, 1990; Ibrahim, 2008; 
E. Omar, 1980). Therefore, the Orang Asli are still left behind as according to Daes's view on the understanding the rights for self-determination which is 'to encourage the state to share power democratically under a constitutional formula and to guarantee effective representatives' (Daes, 1996 p.256). It is evident that the Orang Asli are still under the governance and are controlled by the political system and party which are not among them.

This can be proven even further in terms of financial provision which is handled by the Ministry itself and not among the Orang Asli. Even though every year the financial provision for the Orang Asli education increases, (see in the Report of Department of Orang Asli Development, 2011) the administration of the finance is still under the control and administered by JAKOA and not by the Orang Asli themselves. It is evident that, autonomy in terms of management of funding is limited because it is managed by JAKOA and education institutions, again, which are not among the Orang Asli.

However this contradicts with the Art 4 in UNDRIP which highlights the autonomy funding which is '...as well as ways and means for financing their autonomous functions' (p.4). Orang Asli are not in the positions that can give them dominant power within their own country. The Orang Asli have been denied their full and equal participation in the political process which affects the formation of the policy especially in the education system because they do not have a political party which can lead them to self-government. The implemented education policy is still being controlled by the government like the financial provision in the making of a policy. Therefore, full rights to self-determination through guidelines outlined by UNDRIP in the Art 3, 4 and 14 are limited. It can also be seen that Orang Asli and Aboriginal peoples' current self-determination is contradicting to Anaya's views of self-determination which is '...administrative autonomy by Indigenous people' (2004 p.150). The existing political, legal, and administrative systems of the state have weakened and dissolved the traditional political organization of the Orang Asli. Their rights of self-government and autonomy are a long way off from the minimum standards set under the international law.

\section{Cultural and Curriculum}

The first curriculum by the Ministry of Education Malaysia is Curriculum for Orang Asli-Penan (KAP). This curriculum is managed by the Ministry of Education Malaysia Curriculum Development Centre (Ministry of Education Malaysia, 2012b). Feedbacks or inputs about the establishment of this curriculum were gained from some of the Orang Asli representatives including Senator Osman Bongsu (Orang Asli Senator at that time), scholars and teachers. This curriculum was then approved by the Federal Curriculum Committee, Ministry of Education Malaysia and the implementation was effective in March 2007 at several schools as pilot projects (Ministry of Education Malaysia, 2012c). KAP is referred to as the new curriculum which instilled client needs, experience, and environment (Ramlah, 2009). This client-based curriculum (Orang Asli or Penan students are the clients) can be regarded as a new initiative towards the development of community through education for the minorities. This initiative is also parallel to the effort made by the Government in developing human capital through a provision of education service which is more relevant, compatible and responsive to the client's requirements. The relevance of the curriculum can be identified from its objectives, aims, and the implementation strategies. The mission of KAP is to produce knowledgeable and well-mannered Orang Asli/Penan students, who also love their school life and their 
sociocultural, and who could adapt with the global society (see the Report of Ramlah, 2009). These missions fundamentally uphold the national education philosophy, which also aimed to integrate the minorities into the mainstream society - no one is isolated or abandoned.

To ensure the success of the empowerment process, a well-designed curriculum that supports the process with certain practices has been constructed. These practices can be in the form of activities, curriculum, pedagogy, learning environment, school system and governance, special schemes (including benefits and aids) as well as general community involvement. All of these practices would then form an empowering learning environment. The teachinglearning process is cored with the native pedagogy where artefacts and materials are available in the sociocultural environment and used as teaching aids or to describe the contents of the lessons. It is vital to ensure that the learning and teaching system to be stimulating. The pedagogy method which takes into account its culture and their life style can ensure that the teaching session to be more effective and also can increase the self-esteem of the Orang Asli students. According to Hasan (2009), the teaching and learning method is an important element in ensuring the effectiveness of the education system for the Orang Asli. This is because Orang Asli students need the special attention as compared to mainstream students given the fact of the different lifestyle, perspective and thoughts.

Besides, another issue in the education system that should be focussed on is the implementation of the curriculum. It is important to ensure that the curriculum to be comprehensive and holistic unlike the implementation of KAP by MoE which is considered as not being holistic and lacking of experienced teachers in conducting the curriculum (see the report of SUHAKAM, 2010, 2011b). Even though there are Institutes of Teacher Education (IPG), as well as indigenous resources for the research studies in all five National Indigenous Pedagogy Excellence Centre, the involvement of the Orang Asli as teachers is very minimal (see in the Report of Department of Orang Asli Affairs, 2008). This is important because the accomplishment of the curriculum is depending on the teacher's ability to understand and fathom the needs and wants of the curriculum and the Orang Asli's community. Therefore, teachers have to become the mediators between the school and the Orang Asli's community to ensure that the Indigenous Knowledge is reached and successfully implemented in conjunction to the Article 14 (1) which states that 'Indigenous peoples have the right to establish and control their educational systems and institutions, providing education in their own languages; in a manner appropriate to their cultural methods of teaching and learning' (UNDRIP, 2007, p. 7).

If the existed Orang Asli education policy were to be inspected, it can be seen that the Indigenous pedagogy, element and cultural awareness towards Orang Asli are not specifically introduced to the Orang Asli. Even though with the existence of curriculum such as KAP and Special Model School, as stated in the previous government reports, those are just a 'report on a piece of paper'. Therefore from the implementation, it can be argued that the curriculum and the pedagogy are not executed fully in the school level which is why the Orang Asli Schools are still using the same curriculum and teaching pedagogy as the mainstream students. This was reported by SUHAKAM during their visits to the Orang Asli schools (SUHAKAM, 2010, 2011b, 2012). Therefore, the government should pay attention to these 
weaknesses and fix the implementation, and a complete evaluation should be done so the agendas outlined can be achieved.

\section{Language}

The Orang Asli are still using Malay and English language and the structure from the mainstream curriculum as a teaching medium and sources in the education system. Therefore, Orang Asli are still given the full opportunity to create a curriculum and education orientation which is based on the culture through the implementation of the language and culture in their education system. Malaysia owes it to the Orang Asli to support the maintenance and revival of their cultural heritage, in this instance, through language revival. To quote Nelson Mandela, 'if you talk to a man in a language he understands, that goes to his head. If you talk to him in his language, that goes to his heart' (cited from Zuckermann, Shakuto-Neoh, \& Quer, 2014, p. 57). According to the international law of Indigenous people human rights, Article 14 (3) states that, 'states shall, in conjunction with Indigenous people, take effective measures, in order for Indigenous individuals, particularly children, including those living outside communities, to have access, when possible, to an education in their own cultural setting and provide in their own language' (UNDRIP, 2007, p. 7). Thus every person has the right to express themselves in the language of their ancestors (Odugu \& Lemieux, 2019), not just in the language of convenience like what Malay language has become. Through supporting language revival, government of Malaysia can appreciate the significance of Orang Asli languages and recognizes their importance to the Orang Asli and to Malaysia through education and constitution. Government can then amend some small parts of the wrongs against the original inhabitants of this country and support the wishes of their ancestors with the help of linguistic knowledge. For example, New Zealand, South Africa, Norway and Peru are significant examples of language preservation and restoration for Indigenous people in their countries by making the aboriginal peoples' languages as official language along with other languages in their countries (Mohd Roslan, 2016, 2018). This is an example on how the government gives the language rights and recognition to Indigenous people. Language equity and rights are not just by providing the subject Bahasa, it is more than that. It is to elevate Bahasa Orang Asli in the education system. Bahasa Orang Asli should be the language of knowledge and language of instruction for the Orang Asli schools (Alias, 2015). Based on Zuckermann (2012) '..emphasis often seems to be more on land than language but while compensation can be given for land, that is not possible for the loss of a language...when a language is lost, people also lost their intellectual sovereignty and their culture'. Therefore, the government should provide funding and mechanism in realizing this matter by providing trained teachers who master the language of the Orang Asli so that the wish in the Article 14 can be fulfilled.

\section{Conclusion}

As a conclusion, Orang Asli are not given the opportunity to create a curriculum and educational orientation based on their own culture. By integrating them into the mainstream education system, the government believes that it is an approach that can help the Orang Asli to escape from poverty. But after nearly 20 years of ongoing education integration, the Orang Asli are still remain in poverty and the education gap is widening. While there are efforts to incorporate elements of equity in education but it is more to solve problems concerning to the disadvantages in the mainstream education for Orang Asli rather than integrating the 
mentioned aspect. However, this effort has failed in ensuring the Orang Asli's equal rights in education. Recognition and inclusion of the Orang Asli in the educational arena are also fundamental in any reports that have been discussed unfortunately the concept of recognition and the rights of the Orang Asli are mentioned through the view of the government rather than the view of the Orang Asli themselves. Therefore, plan or policy is not carried out in conformity with the requirements and is also not inclusive in resolving and giving the educational rights to the Orang Asli.

The concept of 'equity' is the theme which travels through the ages in line with the interests of the individual rights of the Orang Asli community in discussing issues concerning education. For example, the recognition of indigenous rights through KAP involves curriculum reform and an increase in the number of indigenous educators and researchers. The government also provides education funding with major equity initiative which aims to increase the number of the Orang Asli students through individual financial aid to students and school facilities. However, most of the government's focus is on materials and percentage figures. The government failed to focus on the contents designed, pedagogy, curriculum and teaching and learning process which should have ensured equity among the Orang Asli as how the equity exist in the mainstream society. For example, the government must also recognize the rights, culture, way of life of the Orang Asli, their indigenous knowledge and their language in the education system. Orang Asli rights must be clarified in the education system through the requirements and also the educational model so that they are not isolated from the existing education system. Therefore, full involvement of the Orang Asli is necessary in terms of the management, administration, and the delivery of the mainstream education, so that the education system operates more inclusively towards the curriculum development in line with the UNDRIP.

Drawing from the UNDRIP, this paper has focused on key aspects of tension in Indigenous education policy including cultural, language, pedagogy and self-determination in Education system. The UNDRIP is the most advanced and comprehensive international instrument that protects on the rights of Indigenous people, for their survival, dignity and well-being. Therefore, government of Malaysia should take an important and positive step approach towards the recognition of Indigenous Education rights through the adoption of the UNDRIP in their practice and constitution to recognise Indigenous languages, cultures and Indigenous knowledge in the education system in line with mainstream society.

\section{Acknowledgement}

The authors would like to thank the followings: Department of Orang Asli Development and University of South Australia for technical support and advice especially my supervisor, Assoc. Prof Dr Peter Gale, University of South Australia; Universiti Putra Malaysia and Kementerian Pendidikan Malaysia (Scheme SLAB/SLAI) for the financial support and those involved in this research. Some of the contents in this paper were excerpted from various chapters of MRR's $\mathrm{PhD}$ thesis and a paper presented at International Conference on Access to Justice for Indigenous People at Centre for Malaysian Indigenous Studies \& Faculty of Law, University of Malaya, Malaysia. 


\section{Corresponding Author}

Mohd Roslan Rosnon, Department of Social \& Development Sciences, Faculty of Human Ecology, Universiti Putra Malaysia, 43400 Serdang, Selangor, Malaysia.

Email: roslan_rosnon@upm.edu.my

\section{References}

Alias, A. G. (2015). The teaching of Indigenous Orang Asli language in Peninsular Malaysia. Procedia - Social and Behavioral Sciences, 208(2015), 253-262.

Anaya, J. S. (2004). Indigenous Peoples in International Law (2nd ed.). United Kingdom: Oxford University Press.

Andaya, L. Y. (2001). The search for the 'Origins' of Melayu. Journal of Southeast Asian Studies, 32(3), 315-330.

Asnarulkhadi, A. S. (2005). Orang Asli: Mainstreaming minority consumers. In Y. Nurizan, O. Mohd Amin \& H. Sharifah Azizah (Eds.), Consumers in The Development (pp. 264-276). Serdang: Universiti Putra Malaysia.

Asnarulkhadi, A. S., Maria, M., Zahid, E., Mariani, M., \& Hanina, H. H. (2007). Integrated curriculum for Orang Asli/Penan (KAP): A new approach in community education development among the Orang Asli/Penan. Paper presented at the National Seminar of Social Science: Sains Sosial Teras Pembangunan Modal Insan, Kuala Lumpur.

Bowen, G. A. (2009). Document analysis as a qualitative research method. Qualitative Research Journal, 9(2), 27-40.

Carey, I. (1976). Orang Asli, the aboriginal tribes of Peninsular Malaysia. Kuala Lumpur: Oxford University Press.

Daes, E. I. (1996). The right of Indigenous Peoples to 'Self-Determination' in the contemporary world order. In D. Clark \& R. Williamson (Eds.), Self-Determination: International Perspectives. New York: St. Martin's Press.

Department of Orang Asli Affairs. (1995). Memorandum pengambilan Sekolah-sekolah Jabatan Hal Ehwal Orang Asli (JHEOA). Kuala Lumpur: Department of Orang Asli Affairs (JHEOA).

Department of Orang Asli Affairs. (2001a). Isu-isu pembangunan Masyarakat Orang Asli (Kertas No. 2/2001). Kuala Lumpur: Department of Orang Asli Affairs (JAHEOA).

Department of Orang Asli Affairs. (2001b). Isu-isu Pembangunan Pendidikan Masyarakat Orang Asli (Kertas No. 3/2001). Kuala Lumpur: Department of Orang Asli Affairs (JAHEOA).

Department of Orang Asli Affairs. (2002a). Pelan Tindakan Pembangunan Pendidikan Masyarakat Orang Asli Kawasan Pinggir 2002. Kuala Lumpur: Department of Orang Asli Affairs (JHEOA).

Department of Orang Asli Affairs. (2002b). Pelan Tindakan Pembangunan Pendidikan Orang Asli 2001-2012. Kuala Lumpur: Department of Orang Asli Affairs (JAHEOA).

Department of Orang Asli Affairs. (2008). The Basic Data of Orang Asli. Department of Orang Asli Affairs: Department of Planning and Research.

Department of Orang Asli Development. (2011). Pelan Strategik Jabatan Kemajuan Orang Asli 2011-2015. Kuala Lumpur: Department of Orang Asli Development (JAKOA).

Derrida, J. (2006). The Politics of Friendship (4th ed.). London: Verso.

Economic Planning Unit. (2010). Tenth Malaysia Plan (2011-2015). Putrajaya: Office Of The Prime Minister Of Malaysia. 
Gilbert, J., \& Doyle, C. (2011). A new dawn over the land: Shedding lights on coleective ownership and consent. In S. Allen \& A. Xanthaki (Eds.), Reflections on the UN Declaration on the Rights of Indigenous Peoples. Australia: Hart Publishing.

Hasan, M. N. (1997). The study about academic achievement among the Indigenous primary school student. Bangi: Universiti Kebangsaan Malaysia.

Hasan, M. N. (2009). Cabaran pendidikan Orang Asli di Malaysia. In A. Abdul Razak \& M. J. Zalizan (Eds.), Masyarakat Orang Asli: Pespektif Pendidikan dan Sosiobudaya (pp. 217228). Bangi: Universiti Kebangsaan Malaysia.

Hasmah, A. M. (2013). Hak pendidikan kanak-kanak Orang Asli. Malaysian Journal on Human Rights, 7, 56-69.

Hood, S. (2004). Dunia Peribumi dan Alam Sekitar: Langkah ke Hadapan. Bangi: Universiti Kebangsaan Malaysia.

Hussain, A. A. (1990). Pembentukan dasar awam Malaysia: Hubungannya dengan politik, UMNO dan birokrasi (2nd ed.). Kuala Lumpur: Utusan Publications and Distributors Sdn. Bhd.

Ibrahim, M. (2008). Dasar Awan di Malaysia: Suatu Pengenalan. Petaling Jaya: IBS Buku Sdn Bhd.

Ikram, J. (1997). Kenyataan Ketua Pengarah Jabatan Hal Ehwal Orang Asli Malaysia pada perjumpaan dengan wakil-wakil media massa pada 31hb. Oktober, 1997 [Press release]

Ministry of Education Malaysia. (2012a). Pelan Pembangunan Pendidikan Malaysia 20132025. Putrajaya: Ministry of Education Malaysia.

Ministry of Education Malaysia. (2012b). Pelan Strategik Interim Kementerian Pelajaran Malaysia 2011-2020. Putrajaya: Ministry of Education Malaysia.

Ministry of Education Malaysia. (2012c). Plan Transformasi Pendidikan Orang Asli Kebangsaan 2012. Putrajaya.

Johdi, M. S., \& Razak, A. (2009). Kesedaran pendidikan dalam kalangan masyarakat Orang Asli. In A. Abdul Razak \& M. J. Zalizan (Eds.), Masyarakat Orang Asli: Pespektif Pendidikan dan Sosiobudaya (pp. 47-62). Bangi: Universiti Kebangsaan Malaysia.

Asri, M. H. (2012). Advancing the Orang Asli through Malaysia's Clusters of Excellence Policy. Journal of International and Comparative Education, 1(2), 90-103.

Roslan, M. R. (2010). Penggunaan Barangan dan Perkhidmatan Sebagai Petunjuk Pembangunan Komuniti Orang Asli Di Daerah Jelebu, Negeri Sembilan. (Master Thesis), Universiti Putra Malaysia, Serdang.

Roslan, M. R. (2013). Challenges of the Orang Asli's rights in mainstream education in Malaysia: An overview. Paper presented at the International Language and Education Conference, Negeri Sembilan, Malaysia.

Roslan, M. R. (2014). Challenges on the Orang Asli's rights in mainstream education in Malaysia: An overview. Malaysian Journal on Human Rights, 57-72.

Roslan, M. R. (2016). Indigenous Education Policies in Malaysia and Australia: A Study of The Recognition of Indigenous Rights and Self-Determination. (Unpublished Doctoral Thesis), University of South Australia, South Australia.

Roslan, M. R. (2018). Keterancaman Bahasa Orang Asli. In S. G. Sarjit \& R. Mohd Roslan (Eds.), Pembangunan Kontemporari Orang Asli (pp. 84-100). Serdang: Universiti Putra Malaysia. 
Roslan, M. R., Mansor, A. T., \& Fahada, N. A. W. A. R. (2019). Self-determination of Indigenous Education Policies in Australia: The case of the Aboriginal People and Torres Strait Islander People. Pertanika Journal of Social Sciences and Humanities, 27(S1), 267-284.

Roslan, M. R., \& Sara, C. (2015). Discourse of Indigenous Education Policy: The Malaysian case. International Journal for Innovation Education and Research, 3(10), 126-140.

Roslan, M. R., Sarjit, S. G., Azahari, S, Z. B., Fahada, N. A. W. A. R., \& Danial, A. H. G. (2019). Petunjuk pembangunan komuniti orang Asli: Suatu analisis penggunaan barangan dan perkhidmatan. Geografia-Malaysian Journal of Society and Space, 15(1), 132-146.

Nicholas, C. (2005). Integration and modernization of the Orang Asli: The impact on culture and identity. Paper presented at the Paper presented at the 1st International Conference on the Indigenous People, Kuala Lumpur.

Nicholas, C. (2006). The state of Orang Asli Education and its problems. Paper presented at the Human Rights Commission of Malaysia (SUHAKAM), Kuala Lumpur.

Odugu, D. I., \& Lemieux, C. N. (2019). Transitional multilingual education policies in Africa: Necessary compromise or strategic impediment?. Language and Education, 33(3), 163-281.

Omar, E. (1980). Policy Analysis and Development in Malaysia. Kuala Lumpur: Institut Tadbiran Awam Negara.

Omar, O. (2004). Politic and Development Among The Orang Asli in Pahang. (Master Thesis), Universiti Putra Malaysia, Serdang.

Ramlah, A. R. (2009). The Report of Pilot project on Curriculum of Education Among Orang Asli and Penan People. Pahang: Intitut Pendidikan Guru Kampus Tengku Ampuan Afzan.

Rohaida, N., \& Witbrodt, M. A. (2012). Self-Determination of Indigenous Peoples: The Case of Orang Asli. Asia Pacific Law Review, 2(2), 189-210.

Salbiah, I. (2007). Support and initiative the Ministry of Education to Orang Asli students. Paper presented at the Eradication of Poverty among The Indigenous People Seminar, Fakulti Ekonomi dan Pentadbiran Universiti Malaya.

Sarjit, S. G., Roslan, M. R., \& Ma'rof, R. (2010). Acculturation of consumerism among the Orang Asli community in Jelebu, Negeri Sembilan. Pertanika Journal of Social Science and Humanities, 18(2), 321-331.

Sharifah, M. N., Shamsilah, R., Aminuddin, M., Kamaruddin, A. H., Azhar, M. A., \& Jaimah, A. M. (2011). Dropout prevention initiatives for Malaysian Indigenous Orang Asli children. The International Journal on School Disaffection, 42-56.

Subramaniam, Y. (2011). Rights denied: Orang Asli and rights to participate in decision making in Peninsular Malaysia. Waikato Law Review, 19(2), 44-65.

SUHAKAM. (2010). Laporan Tahunan SUHAKAM 2010. Kuala Lumpur: Human Rights Commission of Malaysia (SUHAKAM).

SUHAKAM. (2011a). Laporan Maklum Balas Kerajaan Terhadap Laporan Tahunan SUHAKAM 2011. Kuala Lumpur: Human Rights Commission of Malaysia (SUHAKAM).

SUHAKAM. (2011b). Laporan Tahunan SUHAKAM 2011. Kuala Lumpur Human Rights Commission of Malaysia (SUHAKAM).

SUHAKAM. (2012). The status report of child rights education of Orang Asli. Kuala Lumpur: Human Rights Commission of Malaysia.

Sumathi, R. (2016). Educating the Orang Asli children: Exploring indigenous children's practices and experiences in schools. The Journal of Educational Research, 109(3), 275285. 
Tijah, C., \& Joseph, J. (2003). Creating knowledge for change: a case study of Sinui Pai Sengik's educational work with Orang Asli communities in Malaysia. Australia: Asian South Pacific Bureau of Adult Education (ASPBAE).

UNDRIP. (2007). United Nations Declaration of The Rights of Indigenous People. United Nation: Department of Public Information.

UNESCO. (2000). The Dakar framework for action. Education for all: Meeting our collective commitments. Adopted by the World Education Forum Dakar Senegal 26-28 April 2000. Dakar: UNESCO.

United Nation. (2006). 60th sess UN Doc A/RES/60/251. UN GOAR: GA Res.

Zuckermann, G. (2012, 10 September). Language more important than land, Radio New Zealand News. Retrieved from https://www.radionz.co.nz/news/te-manukorihi/115509/language-more-important-than-land-academic

Zuckermann, G., Shakuto-Neoh, S., \& Quer, G. M. (2014). Native tounge title: Compensation for the loss of Aboriginal Language. Journal of Australian Aboriginal Studies(1), 55-71. 